\title{
RANCANG BANGUN ALAT PRAKTIKUM PNEUMATIC DUA SILINDER KATUP SELENOID GANDA PADA LAB.TEKNIK MESIN UMT
}

\author{
ALI ROSYIDIN \\ Program Studi Teknik Mesin. Fakultas Teknik, Universitas Muhammadiyah Tangerang \\ J1. Perintis Kemerdekaaqn I, No.33, Cikokol Kota Tangerang Banten 15118, Indonesia \\ E-mail :rosyidinali90@gmail.com
}

\begin{abstract}
ABSTRAK
Perkembangan teknologi sistem pneumatic yang semakin dibutuhkan di setiap bidang kehidupan manusia, umumnya di dunia industri karena sangat membantu manusia dalam melakukan pekerjaan yang membahayakan keselamatan dan menjadikan aktifitas manusia lebih mudah, praktis dan aman. Perkembangan teknologi ini sejalan dengan perkembangan ilmu pengetahuan, industri dan elektronika. Sistem pneumatic juga memiliki aplikasi yang luas, banyak industri yang menggunakan sistem pneumatic dalam proses produksinya, tentunya mempelajari pneumatic sangat bermanfaat mengingat hampir di semua industri sekarang ini memanfaatkan sistem pneumatic. Maka dengan adanya rancang bangun alat praktikum pneumatic ini bisa menjadikan acuan bagi pendidikan/pelatihan dan juga mempermudah dalam mempelajari/memahami dalam mempraktekan sistem pnumatik..Cara kerja sistem pneumatic menggunakan udara sebagai tenaga penggeraknya, Dalam pneumatic tekanan udara inilah yang berfungsi untuk menggerakan sebuah cylinder kerja. Cylinder kerja ini yang nantinya akan mengubah tenaga/tekanan udara menjadi tenaga mekanik (gerak maju mundur pada cylinder).
\end{abstract}

Kata kunci : Rancang bangun, alat praktikum, pneumatic, cylinder, aplikasi

\section{PENDAHULUAN.}

Perkembangan ilmu pengetahuan dan teknologi pada bidang sistem pneumatic semakin dibutuhkan di setiap bidang kehidupan manusia umumnya di dunia industri Sistem pneumatic sendiri telah banyak diaplikasikan terutama untuk tujuan otomasi pada industri makanan, minuman, otomotif, dan industri berat, sehingga peningkatan Sumber Daya Manusia (SDM) pada bidang pneumatic merupakan langkah strategis yang harus dilakukan sebagai usaha tranformasi teknologi agar mampu berkompetensi secara global.

Rancang bangun alat praktikum ini untuk mempermudah dalam mempelajari cara kerja mekanisme sistem pneumatic dan fungsi operasional komponen-komponen dari sistem pneumatic tersebut serta bagaimana mengaplikasikannya dalam dunia nyata dan juga sebagai alat belajar khususnya di dunia pendidikan.

Tujuan penelitian dapat membuat alat praktikum pneumatic, dari awal pembuatan sampai akhir pembuatan, baik dari segi proses pengerjaan maupun penggunaan bahan yang di perlukan.
Untuk memudahkan kegiatan praktikum dan kegiatan belajar khususnya pada dunia pendidikan.. Agar mahasiswa/pelajar dapat menerapkan ilmu pengetahuan yang di pelajari dan mengalami segala macam permasalahan yang timbul dalam pembuatan alat praktikum pneumati guna dapat diterapkan dalam dunia industri atau bidang wirausahaan.

Manfaat penelitian memperkuat dan menumbuhkan kemampuan inovasi bagi perguruan tinggi/Sekolah dalam menggali dan meningkatkan kualitas produk. Untuk membantu proses pembelajaran pneumatic melalui simulator (alat peraga). Sebagai bahan kajian pembalajaran khususnya matakuliah elektro pnumatik Diharapkan memberikan kontribusi yang positif terhadap pengembangan aplikasi ilmu dan teknologi, khususnya pada jurusan Teknik Mesin di Universitas Muhammadiyah Tangerang. Bagi pembaca diharapkan dapat dipakai menjadi referensi untuk disiplin ilmu yang ditekuni atau dipelajari. 


\subsection{Pneumatic}

Istilah Pneumatic berasal dari bahasa Yunani, yaitu 'pneuma' berart napas atau udara, pneumatic selalu berhubungan dengan teknik penggunaan udara bertekanan, sehingga pneumatic merupakan ilmu yang mempelajari teknik pemakaian udara bertekanan (udara kempa). (Andrew Parr. 2003)

Cara kerja sistem pneumatic sama dengan hidrolik yang membedakan hanyalah tenaga penggeraknya, pneumatic menggunakan udara sebagai tenaga penggeraknya, sedangkan hidrolik menggunakan cairan oli sebagai penggeraknya. Dalam pneumatic, tekanan udara ini berfungsi untuk menggerakan sebuah cylinder kerja. Cylinder bekerja mengubah tenaga/tekanan udara menjadi tenaga mekanik (gerak maju mundur pada cylinder).

Sistem pneumatic digunakan untuk aplikasi yang sangat luas karena udara pneumatic bersih dan mudah di dapat. Banyak industri yang menggunakan sistem pneumatic dalam proses produksi seperti industri makanan, industri obatobatan, industri pengepakan barang maupun industri yang lain. Belajar pneumatic sangat bermanfaat mengingat hampir di semua industri sekarang memanfaatkan sistem pneumatic.

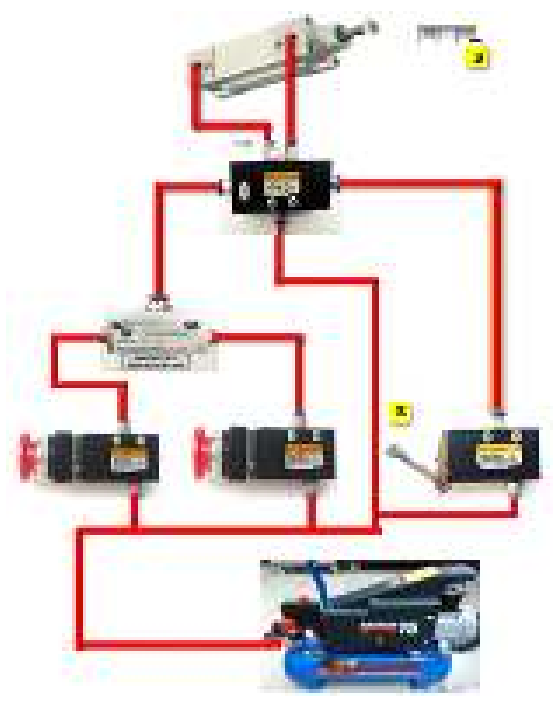

Gambar 2.1 Sistem Pneumatic

\subsection{Karakteristik Udara Kempa Pada Pneumatic}

Udara dipermukaan bumi ini terdiri atas campuran dari bermacam-macam gas. Komposisi dari macam-macam kandungan gas tersebut anatara lain sebagai berikut (Wirawan dan Pramono, 2004 : 458). a. Nitrogen $(\mathrm{N})$ : yang memiliki volume prosentase sebesar $78 \%$.

b. Oksigen $\left(\mathrm{O}_{2}\right)$ : yang memiliki volume prosentase sebesar $21 \%$

c. Gas-gas lainnya yaitu : Carbon, Dioksida, Helium, Neon dan Xenon.

Dalam sistem pneumatic udara difungsikan sebagai media transfer dan penyimpanan tenaga (daya), dengan cara dikempa (dipampatkan). Udara termasuk golongan zat fluida karena sifatnya yang selalu mengalir dan bersifat compressible (dapat dikempa). Sifat-sifat udara mengikuti hukum-hukum gas.Karakteristik udara diidentifikasi sebgai berikut :

1. Udara mengalir tekanan tinggi ke tekanan rendah.

2. Volume udara tidak tetap

3. Udara dapat dikempa (didapatkan)

4. Berat jenis udara $1,3 \mathrm{~kg} / \mathrm{m}^{3}$

5. Udara tidak berwarna

\subsection{Efektifitas Pneumatic}

Sistem gerak dalam pneumatic memiliki optimalisasi/efektifitas bila digunakan pada batasbatas tertentu. Adapun batas-batas ukuran yang dapat menimbulkan optimalisasi penggunaan pneumatic antara lain :

1. Diameter piston antara $6 \mathrm{~s} / \mathrm{d} 320 \mathrm{~mm}$

2. Panjang langkah $1 \mathrm{~s} / \mathrm{d} 2.000 \mathrm{~mm}$

3. Tenaga yang diperlukan $2 \mathrm{~s} / \mathrm{d} 15$ bar

Untuk keperluan pendidikan umumnya berkisar antara 4 sampai dengan 8 bar, dapat juga bekerja pada tekanan udara di bawah 1 atmosfer (vacuum), misalnya untuk keperluan mengangkat plat baja dan sejenisnya melalui katup karet hisap flexibel. Adapun efektivitas penggunaan udara bertekanan dapat dilihat pada grafikberikut:

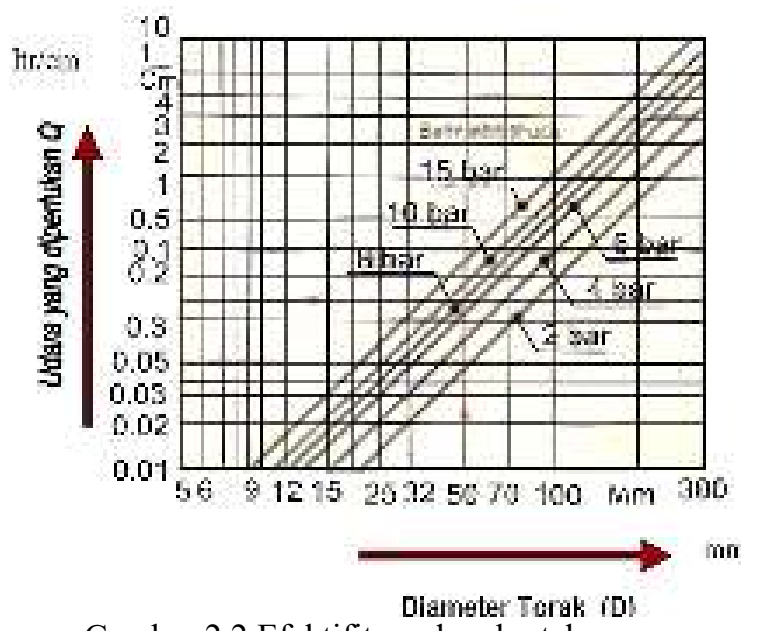

Gambar 2.2 Efektifitas udara bertekanan (Werner Rohrer,1990) 


\section{METODELOGI PENELITIAN}

\subsection{Persiapan Penelitian}

Sebelum penelitian dilakukan, terlebih dahulu, melakukan penelitian merancang bentuk dan ukuran pada alat, simulator dan mempersiapkan bahan-bahan dan peralatanperalatan yang akan digunakan untuk penelitian.

\subsection{Desain Produk}

Selanjutnya membuat rancang bangun alat praktikum pneumatic dua silinder katup solenoid ganda dengan langkah sebagai berikut :

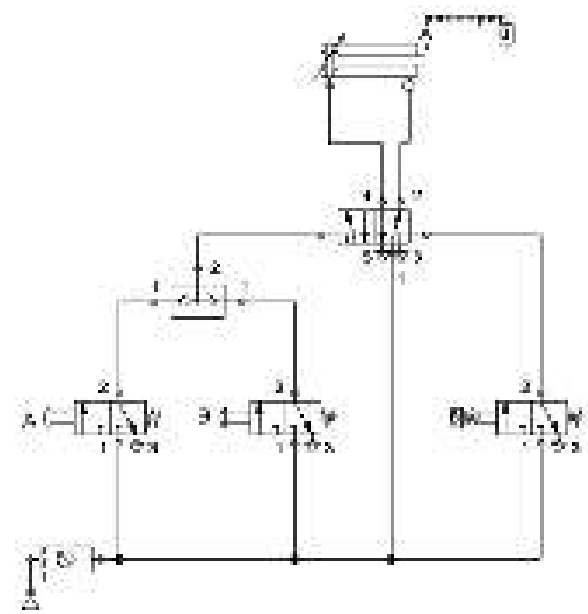

Gambar 3.1 Diagram Rangkaian Pneumatic Dua Silinder Katup Selenoid Ganda

\subsubsection{Pembuatan Alat}

Adapun langkah-langkah dalam membuat rangkaian Perancangan desain bentuk rangkaian pneumatic dua silinder katup solenoid ganda yaitu :

a. Gambar serta ditentukan ukurannya

b. Pilih bahan yang akan digunakan untuk membuat rangkaian pneumatic.

c. Dilakukan pengukuran terhadap bahanbahan yang akan digunakan dengan ukuran yang telah ditentukan.

d. Potong bahan sesuai dengan ukuran yang telah ditentukan.

e. Dibentuk dan dilakukan pengelasan pada besi siku dan pengeboran untuk membentuk kerangka pada alat.

f. Digerinda permukaan yang terlihat kasar karena proses pengerjaan.

g. Dilakukan pengecetan pada rangka guna memperpanjang umur pemakaian alat dan menambah daya tarik pada alat pneumatic.

\subsubsection{Kebutuhan Bahan Penelitian}

Kebutuhan alat dan bahan lihat tabel 3.1 sebagai berikut :

Ali Rosyidin
Tabel 3.1 Bahan Utama

\begin{tabular}{|c|c|c|c|c|}
\hline No & Bahan & Ukuran & Satuan & Q'ty \\
\hline 1 & Besi Siku & $\begin{array}{l}\text { Panjang }=6 \mathrm{~m} \\
\text { Tebal }=2 \mathrm{~mm} \\
\text { Lebar }=3 \mathrm{~cm}\end{array}$ & Meter & 1 \\
\hline 2 & Papan & $\begin{array}{l}\text { Panjang }= \\
100 \mathrm{~m} \\
\text { Tebal }=1 \mathrm{~cm} \\
\text { Lebar }=100 \mathrm{~cm}\end{array}$ & $\mathrm{Cm}$ & 1 \\
\hline 3 & Baut & M12 & Pcs & 4 \\
\hline 4 & Roda & & Pcs & 4 \\
\hline 5 & $\begin{array}{l}\text { Silinder } \\
\text { Double / } \\
\text { Silinder } \\
\text { Single }\end{array}$ & $\begin{array}{l}\text { Tipe BSC } \\
32 \times 50\end{array}$ & Pcs & 2 \\
\hline 6 & $\begin{array}{l}\text { Selenoid } \\
\text { Ganda }\end{array}$ & $\begin{array}{l}\text { V5222-084 } \\
\text { Pressure : } \\
0,15-0,8 \mathrm{Mpa}\end{array}$ & Pcs & 1 \\
\hline 7 & $\begin{array}{l}\text { Selenoid } \\
\text { Elektrik }\end{array}$ & $\begin{array}{l}\text { 3V110-06 } \\
\text { Pressure : } \\
0,15-0,8 \mathrm{Mpa}\end{array}$ & Pcs & 1 \\
\hline 8 & $\begin{array}{l}\text { Shuttle } \\
\text { Valve }\end{array}$ & Tipe Ks-02 & Pcs & 1 \\
\hline 9 & $\begin{array}{l}\text { Push } \\
\text { Button }\end{array}$ & $\begin{array}{l}\text { M32-08S1B } \\
\text { Pressure : } 0- \\
0,8 \mathrm{Mpa}\end{array}$ & Pcs & 2 \\
\hline 10 & $\begin{array}{l}\text { Roller } \\
\text { Valve }\end{array}$ & $\begin{array}{l}\text { M32-08S2 } \\
\text { Pressure : } 0 \text { - } \\
0,8 \mathrm{Mpa}\end{array}$ & Pcs & 1 \\
\hline 11 & Regulator & Ukuran 1/4 & Pcs & 1 \\
\hline 12 & Selang & Ukuran 6 & Pcs & 1 \\
\hline 13 & $\begin{array}{l}\text { Nepel/ } \\
\text { Konektor }\end{array}$ & Ukuran 6 & Pcs & 20 \\
\hline
\end{tabular}

\subsection{Perancangan Kerangka Alat Pneumatic}

Kerangka ini berfungsi untuk merakit masing-masing rangkaian pneumatic, yang akan di pasang di bagian dinding meja/papan utama meja dengan menggunakan baut screw sesuai gambar yang sudah di tentukan.

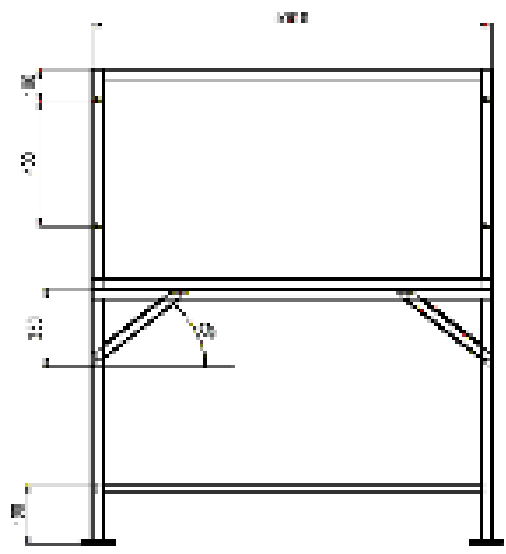


Gambar 3.2 Desain Rangka Pandangan Depan

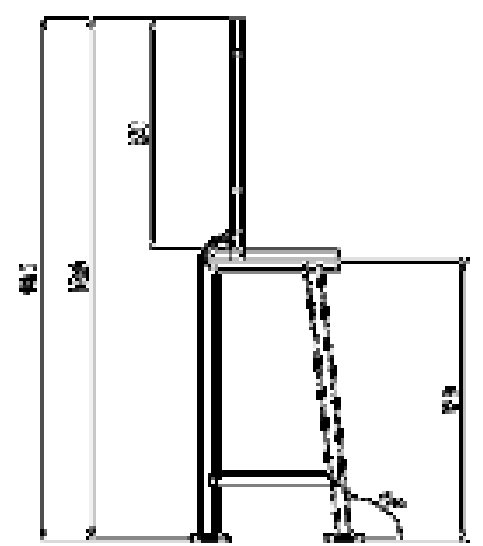

Gambar 3.3 Desain Rangka Pandangan Samping

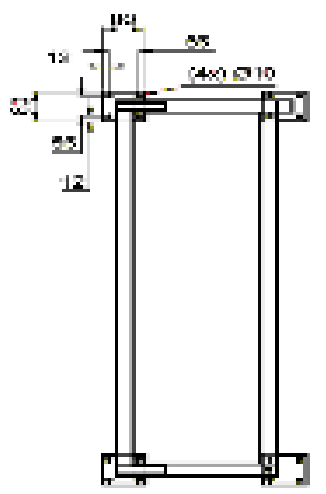

Gambar 3.4 Desain Rangka Pandangan Atas

\subsection{Tahapan Pembuatan Alat}

1. Pemotongan besi siku sesuai ukuran

2. Pengelasan pada besi untuk membuat meja alat.

3. Pembuatan lubang dan pemasangan besi siku yang telah di las.

4. Pemotongan papan kayu dan triplek melamin.

5. Tahap Pemberian Dempul dan Pengamplasan.

6. Pengecetan kerangka meja alat.

7. Perakitan masing-masing rangkaian alat Pneumatic.

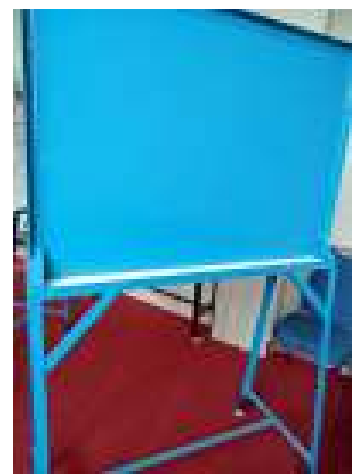

Gambar 3.5 Hasil Pengecetan Kerangka Meja Alat

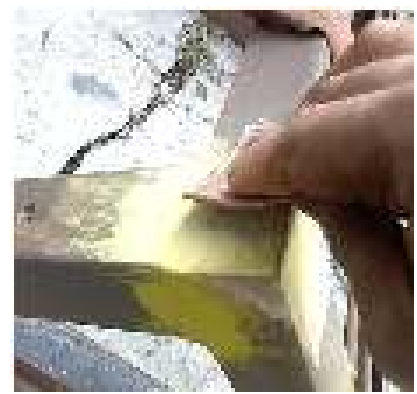

. Gambar 3.6 Tahap Pemberian Dempul dan Pengamplasan

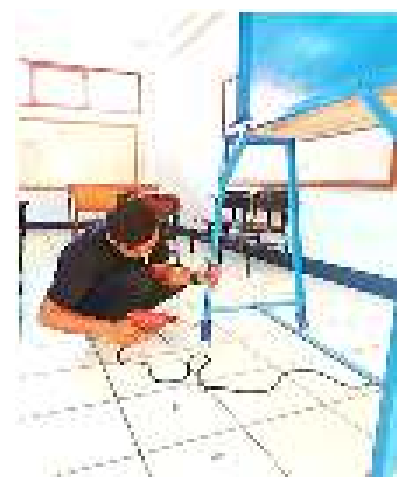

Gambar 3.7 Rangka Yang sedang di Rakit

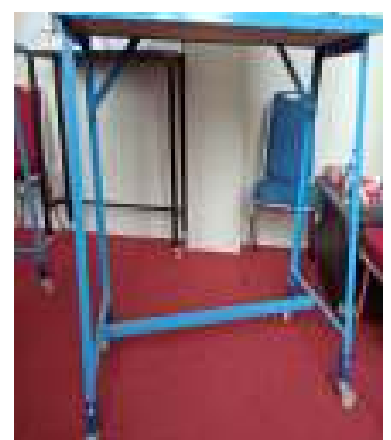

Gambar 3.8 Pemasangan Kaki Roda 


\section{ANALISA DAN PEMBAHASAN}

Langkah-langkah dalam pembuatan dan perakitan meja alat Simulator pneumatic dua silinder katup solenoid ganda yaitu

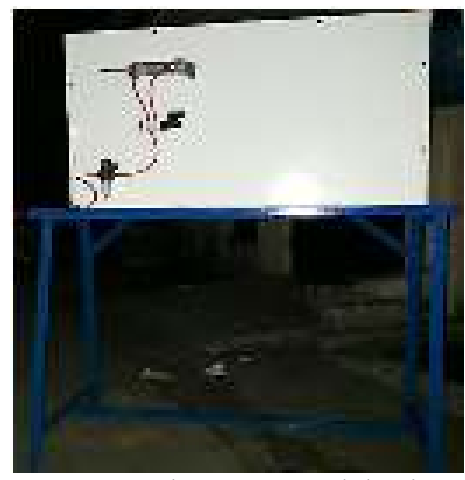

Gambar 4.1 Rangka Yang Sudah Siap dipasang Alat simulator

Perakitan rangkaian pneumatic dua silinder katup selenoid ganda

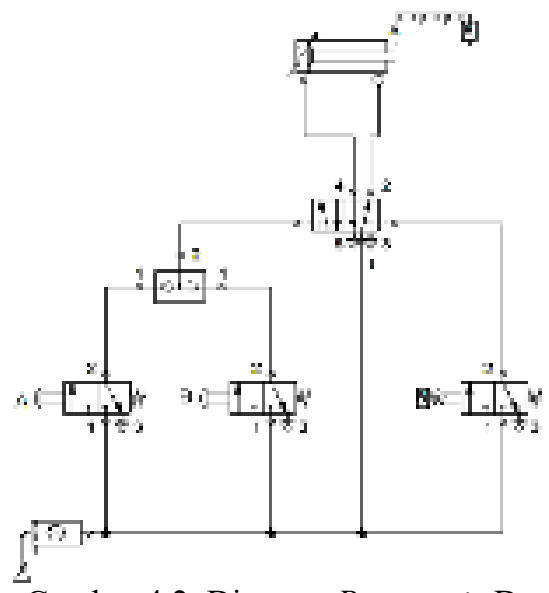

. Gambar 4.2 Diagram Pneumatic Dua Silinder Katup Selenoid Ganda

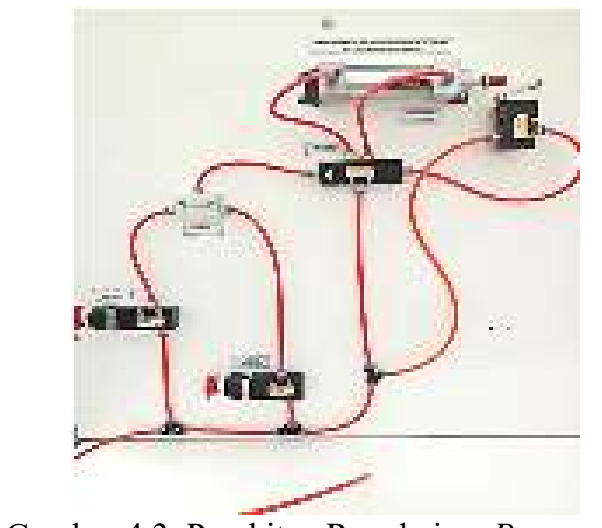

Gambar 4.3 Perakitan Rangkaian Pneumatic
Berdasarkan cara kerjanya, Alat simulator praktikum Pneumatic dua silinder katup selenoid ganda sebagai berikut :

Salah satu push button $\mathrm{A} / \mathrm{B}$ di tekan kemudian angin diteruskan melaluis huttle valve untuk mendorong solenoid ganda. Shuttle valve ini mempunyai dua masukan dan satu keluaran.

Kemudian angin masuk melalui solenoid ganda untuk mendorong silinder, silinder bergerak terdorong oleh angin sampai dengan titik B (Titik B adalah roller valve fungsinya untuk mendorong kembali piston ketitik awal) .LihatGambar 4.11.

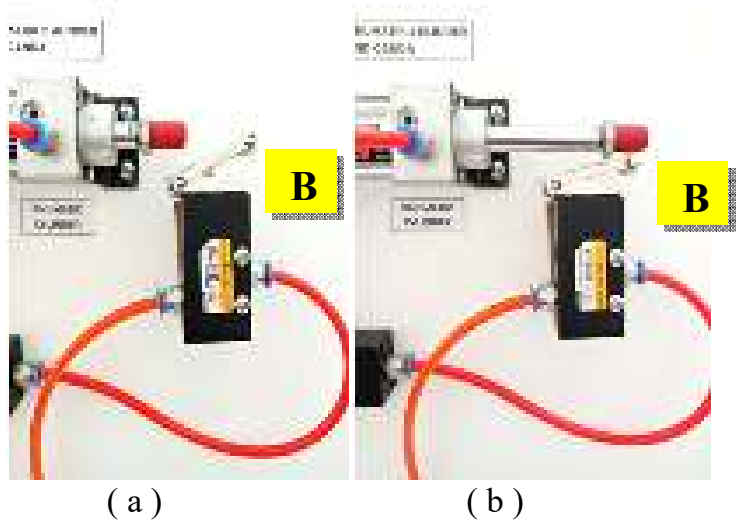

Gambar 4.4 (a) Sebelum Batang Piston Terdorong ke Titik B. (b) Sesudah Batang Piston Terdorong ke Titik B

\subsection{Prinsip Dasar Kerja Pneumatic}

Kompresor diaktifkan dengan cara menghidupkan penggerak mula umumnya motor listrik. Udara akan disedot oleh kompresor kemudian ditekan ke dalam tangki udara hingga mencapai tekanan beberapa bar. Untuk menyalurkan udara kempa ke seluruh sistem (sirkuit Pneumatic) diperlukan unit pelayanan atau service unit yang terdiri dari penyaring (filter), pengatur tekanan (regulator) dan pelumas (lubrikator) bagi yang memerlukan.

Service unit diperlukan karenakan udara kempa diperlukan di dalam sirkuit Pneumatic harus benar-benar bersih, Tekanan operasional udara pada umumnya sekitar 6 bar. Selanjutnya udara kempa disalurkan dengan membuka katup pada service unit, kemudian menekan tombol katup Pneumatic (katup pengarah) hingga udara kempa masuk ke dalam tabung Pneumatic dan akhirnya piston bergerak maju.

\subsection{Cara Kerja Alat Praktikum Pneumatic}




\subsection{Cara Pengoperasian}

1. Menyiapkan kompresor

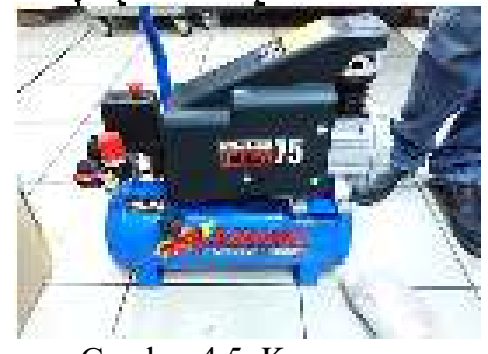

Gambar 4.5 Kompresor

2. Sambungkan selang udara Pneumatic pada kompresor.

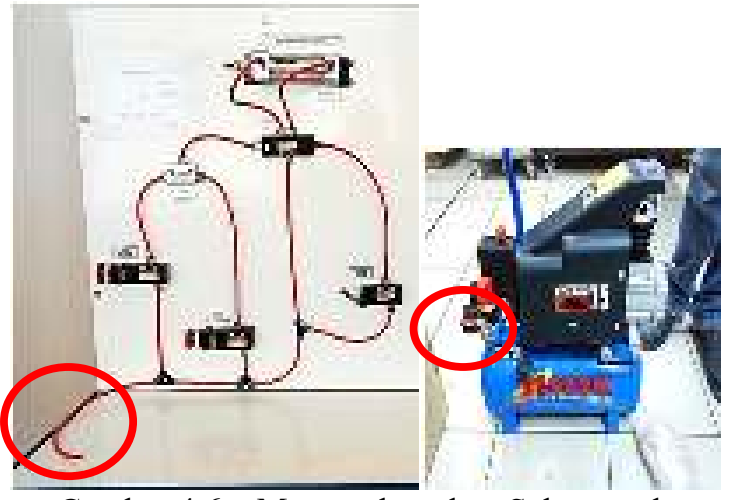

Gambar 4.6 Menyambungkan Selang pada Kompresor

3. Setelah tersambung selang pada kompresor dibuka pada kran angin pada kompresor, lalu atur tekanan udara yang diinginkan dengan cara memutar katup pada regulator. Kompresor akan mengalirkan udara kempa pada masing masing ke seluruh sistem Pneumatic.

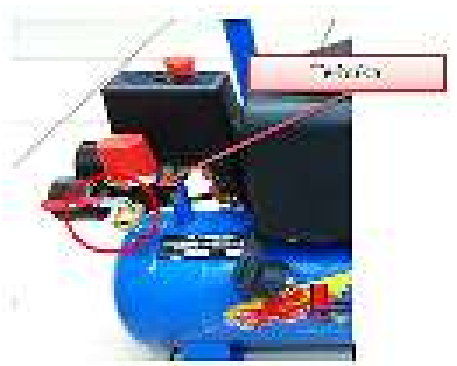

Gambar 4.7 Membuka Kran Angin

4. Tekan salah satu push button $\mathrm{A} / \mathrm{B}$

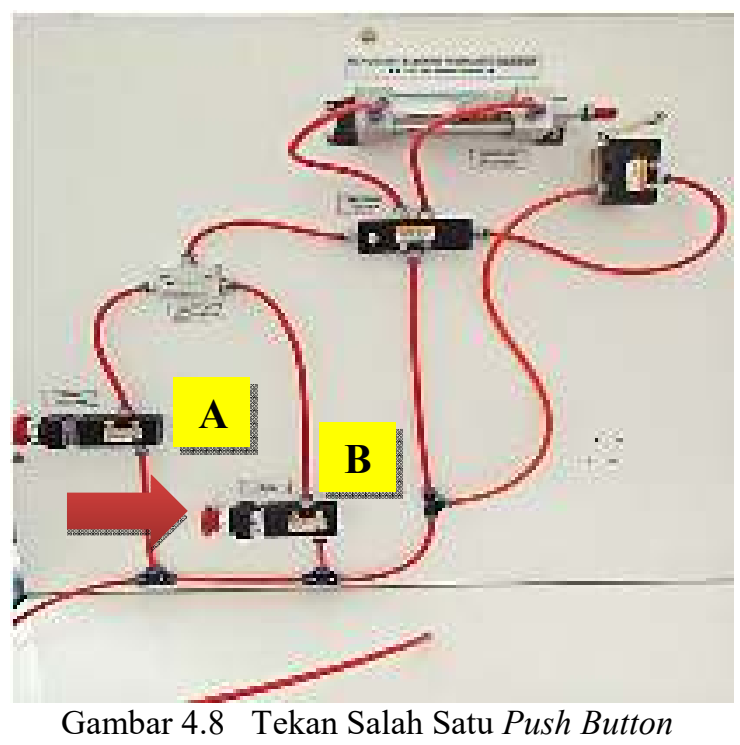

\subsection{Perhitungan}

4.3.1 Perhitungan gaya pada Pneumatic

1.. Gaya efektif piston saat maju

$$
\mathrm{F}_{(\text {maju })}=\mathrm{A} \times \mathrm{P}
$$

Dimana :

$\mathrm{F}=$ Gaya efektif piston saat maju (N) $\mathrm{A}=$ Luas permukaan silinder Pneumatic $\left(\mathrm{m}^{2}\right)$ $\mathrm{A}=\left(\frac{\pi}{4}\left(\mathrm{D}^{2}\right)\right)=\left(\frac{3.14}{4}\left(\mathrm{D}^{2}\right)\right)$

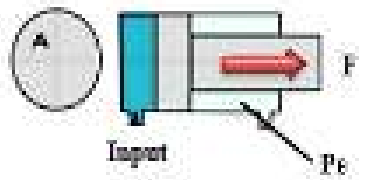

Gambar 4.9 Gaya Efektif Piston Saat Maju

2. Gaya efektif piston saat mundur

$$
\mathrm{F}_{\text {(mundur) }}=\mathrm{A} \times \mathrm{P}
$$

Dimana :

$\mathrm{F}=$ Gaya efektif piston saatmundur (N)

$\mathrm{A}=$ Luas permukaan silinder Pneumatic $\left(\mathrm{m}^{2}\right)$ $\mathrm{A}=\left(\frac{\pi}{4}\right) \times\left(D^{2}-d^{2}\right)$

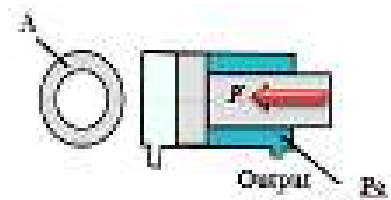

Gambar 4.10 Gaya Efektif Piston SaatMundur

\subsubsection{Konsumsi udara tiap langkah piston}

1. Konsumsi udara pada saat piston maju

$$
\mathrm{V}_{1}=\mathrm{p} \times\left(\frac{\pi}{4}\right) \times \mathrm{D}^{2} \times \mathrm{h}
$$

Dimana : 
$\mathrm{V}=$ Konsumsi udara saat piston bergerak maju $(\mathrm{m} / \mathrm{s})$

$\mathrm{P}=$ Tekanan kerja untuk Pneumatic $\left(\mathrm{N} / \mathrm{m}^{2}\right)$

$\mathrm{D}=$ Diameter piston $(\mathrm{m})$

$\mathrm{h}=$ Panjang langkah $(\mathrm{cm})$

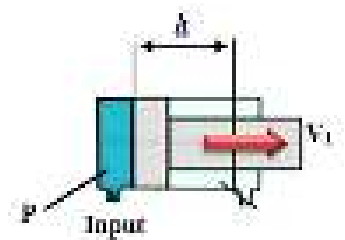

Gambar 4.11 Konsumsi Udara Saat Piston Maju

2. Konsumsi udara saat piston mundur $\mathrm{V}_{2}=\mathrm{P} \times\left(\frac{\pi}{4}\right) \times\left(\mathrm{D}^{2} \times \mathrm{d}^{2}\right) \times \mathrm{h}$

Dimana :

$\mathrm{V}=$ Konsumsi udara saat piston bergerak mundur $(\mathrm{m} / \mathrm{s})$

$\mathrm{P}=$ Tekanan kerja untuk Pneumatic $\left(\mathrm{N} / \mathrm{m}^{2}\right)$

$\mathrm{D}=$ Diameter piston $(\mathrm{m})$

$\mathrm{h}=$ Panjang langkah $(\mathrm{cm})$

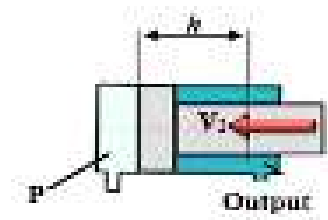

Gambar 4.12 Konsumsi Udara Saat Piston Mundur

\subsubsection{Perhitungan Daya Kompresor}

Debit kompresor :

$\mathrm{Q}_{\mathrm{S}}=\left(\frac{\pi}{4} \times(\mathrm{D})^{2}\right) \times \mathrm{v}$

Dimana :

$\mathrm{Q}_{\mathrm{S}}=$ Debit kompresor (liter/menit)

$\mathrm{D}=$ Diameter silinder $(\mathrm{mm})$

$\mathrm{v}=$ Kecepatan piston $(\mathrm{mm} /$ menit atau (mm/detik)

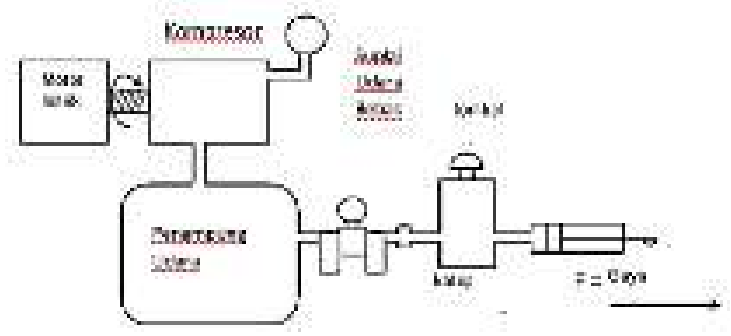

Gambar 4.13 Daya Kompresor

\section{KESIMPULAN}

Dari hasil rancang bangun alat praktikum pneumatic, maka dapat disimpulkan sebagai berikut

1. Rancang bangun alat praktikum pneumatic dua silinder katup selenoid ganda hanya berbentuk simulator/alat pragadan digunakan untuk kegiatan belajar khususnya di dunia pendidikan.

2. Rancang bangun alat praktikum pneumatic dua silinder katup selenoid ganda dapat bekerja sesuai yang diharapkan. Alat praktikum pneumatic ini menggunakan katup selenoid 5/2 untuk pneumatic dua silinder menggunakan selenoid ganda alat praktikum pneumatic ini hanya menggunakan kompresor sebagai alat penggeraknya

3. Hasil dari perhitungan pneumatic dapat disimpulkan maka diketahui Gaya tekan yang dihasilkan adalah sebesar $147.15 \mathrm{~N}$, Perencanaan Diameter silinder $1.8 \approx 2 \mathrm{~cm}$, Panjang langkah yang dibutuhkan 150 mm, Gaya piston saat maju $188.4 \mathrm{~N}$ dan Gaya piston saat mundur $158.33 \mathrm{~N}$, untuk konsumsi udara yang dibutuhkan pada saat piston maju sebesar 0.282liter dan pada saat piston mundur 0.237 liter, sedangkan daya kompresor yang dibutuhkan untuk hasil Debit kompresor sebesar 0.188 liter/menit dan Daya kompresor sebesar $0.21 \mathrm{PK}$.

\section{DAFTAR PUSTAKA.}

Al Antoni Akhmad. Perancangan Simulasi Sistem Pergerakan Dengan Pengontrolan Pneumatik Untuk Mesin Pengamplas Kayu Otomatis. Jurnal Rekayasa Sriwijaya, Vol. 18 No 3 Nopember 2009. ISSN 0852-5366

Adi Dewanto, Dessy Irmawati. Pembelajaran Sistem Hidrolik dan Pneumatik Dengan Menggunakan Automation Studio. Jurnal Pendidikan Teknologi, Vol. 21 No 32013. ISSN 2477-2410

Bliesener, R, et. Al. 2002. Programmable Logic Controller. Festo Didactic GmBH. Dekendorf

Muhammad Subhan, Ari Satmoko. Penentuan Dimensi Dan Spesifikasi Silinder Pneumatik Untuk Pergerakan Tote Iradiator Gamma Multiguna Batan. Jurnal Perangkat Nuklir, Vol. 10 No 2 November 2016. ISSN 19783515

Martino, 2014, Analisa dan Perhitungan Sistem Pneumatik Pada Penggunaan Miniatur Furnitur Multifungsi, Skripsi, Jurusan Teknik Mesin Fakultas Teknik, Jakarta.

Noor Hudallah. Rancang Bangun Sistem Pneumatik Untuk Pengembangan Modul-Modul Gerak Otomatis Sebagai Media Pembelajaran. 
JurnalTeknik Elektro, Vol. 2 No 1 JanuariJuni 2010.

Purnawan, Dian Fitri Diyanto, Uli Karo. Perancangan Simulator Lengan Eskavator Dengan Kontrol Pneumatik. Jurnal Teknik Mesin, Vol. 9 No1 Januari 2013.

Parr.A. 2010. Hidrolika Dan Pneumatika. Jakarta : Erlangga

Said. H. 2012. Aplikasi Programmable Logic Controller (PLC) Dan Sistem Pneumatik Pada Manufaktur Dan Industri. Yogyakarta : Andi

Triyono. Pengaruh Strategi Pembelajaran Dan Kemampuan Analitik Terhadap Keterampilan Pneumatik. Jurnal Teknik Mesin, Universitas Negri Yogyakarta, Vol. 11 No 1 2008. ISSN $1410-4725$

Windarta. Perancangan Mesin Pembersih Untuk Part Internal Alat Berat Dengan Sistem Pneumatik. Jurnal Teknik Mesin, Vol. 10 No 1 2006. ISSN 2549-9645.

Wordpress - Modul Praktikum Hidrolik Pneumatik - 22 Maret 2010

https://thathit.wordpress.com/2010/03/22/cont oh-modul-praktikum-hidrolik-pneumatik/ 